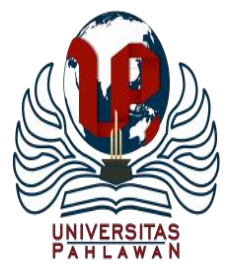

Edukatif : Jurnal Ilmu Pendidikan Volume 3 Nomor 5 Tahun 2021 Halm 2048 - 2059

EDUKATIF: JURNAL ILMU PENDIDIKAN

Research \& Learning in Education

https://edukatif.org/index.php/edukatif/index

\title{
Analisis Persepsi Guru Sekolah Dasar terhadap Pendidikan Seni Musik melalui Pendekatan Rasch Model
}

\author{
Akbar Maulana ${ }^{1 凶}$, Resa Respati ${ }^{2}$, Epon Nur'aeni $\mathbf{L}^{3}$, Muhammad Rijal Wahid Muharram ${ }^{4}$ \\ Universitas Pendidikan Indonesia, Indonesia ${ }^{1,2,3,4}$ \\ E-mail : akbarmaulana@upi.edu ${ }^{1}, \underline{\text { respati@upi.edu }}^{2}, \underline{\text { nuraeni@ }}_{\text {upi.edu }}^{3}, \underline{\text { rijalmuharram@upi.edu }}^{4}$
}

\begin{abstract}
Abstrak
Penelitian ini bertujuan untuk mengetahui tingkat persepsi guru sekolah dasar terhadap pendidikan seni musik. Kegiatan penelitian ini dilakukan dengan mengikuti tahapan metodologi penelitian survei, sehingga proses pegumpulan data dilakukan mengunakan instrumen berupa angket. Subjek dalam penelitian ini adalah guruguru sekolah dasar dalam lingkup kecamatan Rancabali, kabupaten Bandung, Jawa Barat. Data angket yang diperoleh dianalis menggunakan winstep dengan pemodelan rasch. Data hasil pengolahan rasch model kemudian di interpretasi berdasarkan tujuan dari peneliti. Sehingga di ketahui tingkat persepsi guru sekolah dasar terhadap pendidikan seni musik. Berdasarkan penelitian yang dilakukan,tingkat persepsi guru sekolah dasar terhadap pendidikan seni musik menunjukan angka yang baik yaitu $83.65 \%$.
\end{abstract}

Kata Kunci: Persepsi Guru, Pendidikan Seni Musik, Sekolah Dasar.

Abstract

This study aims to determine the level of perception of elementary school teachers on music education. This research activity was carried out by following the steps of the survey research methodology, so that the data collection process was carried out using an instrument in the form of a questionnaire. The subjects in this study were elementary school teachers within the Rancabali sub-district, Bandung district, West Java. The questionnaire data obtained were analyzed using Winstep with Rasch modeling. The data from the processing of the Rasch model is then interpreted based on the objectives of the researcher. So that it is known the level of perception of elementary school teachers on music education. Based on the research conducted, the perception level of elementary school teachers towards music education shows a good number, namely $83.65 \%$.

Keywords: Teacher's Perception, Music Art Education, Elementary School.

Copyright (c) 2021 Akbar Maulana, Resa Respati, Epon Nur'aeni L, Muhammad Rijal Wahid Muharram $\triangle$ Corresponding author

Email : akbarmaulana@upi.edu

DOI $\quad$ : https://doi.org/10.31004/edukatif.v3i5.752

ISSN 2656-8063 (Media Cetak)

ISSN 2656-8071 (Media Online)

Edukatif : Jurnal Ilmu Pendidikan Vol 3 No 5 Tahun 2021 p-ISSN 2656-8063 e-ISSN 2656-8071 
2049 Analisis Persepsi Guru Sekolah Dasar Terhadap Pendidikan Seni Musik Melalui Pendekatan Rasch ModelAkbar Maulana, Resa Respati, Epon Nur'aeni L, Muhammad Rijal Wahid Muharram

DOI: https://doi.org/10.31004/edukatif.v3i5.752

\section{PENDAHULUAN}

Pendidikan adalah usaha sadar dan terencana yang mana dilakukan oleh orang dewasa kepada orang yang belum dewasa guna mengembangkan potensi diri serta kematangan dalam berpikir dan bersikap. Menurut (Maunah, 2009) pendidikan dimaknai sebagai kumpulan pengalaman belajar yang dialami sepanjang hidup dan segala tempat. Hal tersebut tentu sejalan dengan tujuan pendidikan nasional yang dimuat dalam (Undang-Undang Republik Indonesia Nomor 20 Tahun 2003 Tentang Sistem Pendidikan Nasional, n.d.) bahwa pendidikan nasional berfungsi mengembangkan kemampuan dan membentuk watak serta peradaban bangsa yang bermartabat dalam rangka mencerdaskan kehidupan bangsa, bertujuan untuk berkembangnya potensi peserta didik agar menjadi manusia yang beriman dan bertakwa kepada Tuhan Yang Maha Esa, berakhlak mulia, sehat, berilmu, cakap, kreatif, mandiri, dan menjadi warga negara yang demokratis serta bertanggung jawab.

Dewasa ini konsep pendidikan dan pengajaran masih menjadi hal yang kurang terperhatikan, dimana konsep pendidikan dan pengajaran di pahami secara terpisah. Dalam penelitian sebelumnya yang dilakukan oleh (Supardi, 2015) secara umum pendidikan dalam pengembangan kurikulum yang saat ini dilakukan di berbagai sekolah khusnya di sekolah dasar lebih banyak memberikan porsi dalam pengembangan ranah kognitif semata. Selanjutnya sedikit perhatian dalam pengembangan ranah psikomotor atau kinestetik yang bersifat skill. Sementara itu dalam ranah rasa, karsa, dan religi yang menjadi muatan pendidikan karakter atau bersifat afektif kurang mendapat perhatian. Sejalan dengan penelitian tersebut, (Muhyidin, 2012) menyatakan bahwa dalam prakteknya arah pendidikan nasional hanya $95 \%$ menitik beratkan pada pengajaran kepandaian atau dalam hal ini kognitif sedangakan dalam pendidikan moral hanya menjadi pendidikan tambahan belaka aatau dalam hal ini pengembangan kognitif mendapatkan perhatian lebih besar, sementara dalam ranah rasa, karsa dan religi terabaikan.

Salah satu langkah dalam pencapaian tujuan pendidikan adalah dengan melibatkan pelajaran yang memiliki muatan pendidikan. Pendidikan seni terlibat di dalam langkah tersebut khususnya pendidikan seni musik yang saat ini termuat dalam mata pelajaran SBDP di sekolah dasar. Sebagaimana yang di kemukakan Ki hajar Dewantara dalam (Sinaga, 2009; Utomo, 2013) musik merupakan salah satu faktor penentu dalam membentuk kepribadian anak. kesenian merupakan elemen yang esensial dalam pembentukan watak setiap individu dan faktor yang mendasari setiap penciptaan karya seni. Pendidikan seni musik lebih menekankan pada pemberian pengalaman seni musik, yang nantinya akan melahirkan kemampuan untuk memanfaatkan seni musik pada kehidupan sehari hari. Pendidikan Seni musik diberikan di sekolah karena keunikan, kebermaknaan, dan kebermanfaatan terhadap kebutuhan perkembangan siswa, yang terletak pada pemberian pengalaman estetik dalam bentuk kegiatan berekspresi/berkreasi dan berapresiasi melalui pendekatan: "Belajar dengan seni", "Belajar melalui seni" dan "Belajar tentang seni." (Murtiningsih \& Wiryawan, 2007). Adapun manfaat pendidikan seni musik bagi siswa dapat di bagi kedalam tiga aspek utama sebagaimana yang di kemukakan oleh bagian sebagai berikut yang di kemukakan oleh (Respati, 2015) yaitu Aspek Pendidikan : (1) Menguatkan aspek afektif, psikomotor, dan kognitif dalam belajar. (2) Memberikan dasar ekspresi dan kreativitas dalam musik. (3) Menyeimbangkan perkembangan otak kiri dan otak kanan. (4) Sebagai sarana ekspresi, imajinasi, dan kreativitas. (5) Memperkuat suasana dan emosi rileks dalam pembelajaran. Aspek Psikologis : (1) Menyeimbangkan perkembangan jasmani dan rohani anak. (2) Memberikan sarana yang tepat dan positif dalam mengungkapkan perasaan dan kondisi kejiwaan anak. (3) Sarana relaksasi dan kontemplasi. (4) Menumbuhkan sikap kreatif, disiplin, dan menyelesaikan masalah. (5) Menumbuhkan empati dan menghilangkan sikap egoisme dalam diri anak. Aspek Sosial Budaya : (1) Menumbuhkan sikap menghargai, kerja sama, dan berkomunikasi. (2) Memberikan pandangan terhadap budaya sebagai warisan dan kekayaan bagi anak. (3) Menjadi sarana memelihara dan mengembangkan kebudayaan, khususnya seni musik. (4) Menciptakan medan energi yang kuat untuk berinteraksi sesuai etika dan estetika dalam pergaulan. 
Berbeda dari konsep pendidikan seni musik di atas, berdasarkan penelitian yang dilakukan (Kukuh Prabawa et al., 2021) proses atau cara penyampaian pendidikan seni musik masih dilakukan secara setengahsetengah, hal ini berarti berbagai kemampuan peserta didik seperti berekspresi, berapresiasi, berkresi, harmoni, estetika serta pembelajarannya belum memperhatikan karakteristik serta tingkat perkembangan individual peserta didik atau secara sederhananya pembelajaran seni musik yang diterapkan masih hanya terpaku dalam ruang pengajaran pengetahuan dan hiburan saja dan belum sampai pada titik merangsang siswa agar terpicu akan kreativitas dalam mengeksplorasi dirinya sehingga terbentuk karakternya melalui seni musik. Kondisi pembelajaran demikian belum bisa katakan maksimal, karena belum terpenuhinya hakikat pendidikan yang sesungguhnya karena mengabaikan tujuan dari pendidikan seni musik yang mengharuskan siswa mencapai nilai maksimal dari potensinya. Nilai maksimal tersebut tidak terlepas dari dimensi pengetahuan (kognitif), dimensi sikap (afektif), dan keterampilan (psikomotor) (Maunah, 2009; Rofiah, 2016).

Guru dalam hal ini menjadi sorotan terpenting karena dalam pelaksanaannya guru menjadi salah satu komponen utama dari 7 komponen pembelajaran yang dalam hal ini pendidikan seni musik (Pane, 2017). Akan tetapi saat ini kehadiran pendidik atau guru dalam pendidikan seni musik seolah seperti satu-satunya sumber pengetahun dimana guru belum mampu memosisikan dirinya sebagai fasilitator dan pembimbing yang tepat bagi siswa (Kukuh Prabawa et al., 2021). Dalam pendidikan seni musik, khususnya di sekolah dasar guru tidak dituntut harus mahir memainkan seluruh alat musik secara profesional layaknya seorang pekerja seni atau ilmu seni murni (fine art) ataupun harus menjadi seorang pakar seni baru bisa membelajarkan seni musik, dan tidak harus menjadi vokalis terkenal dalam menyanyikan lagu-lagu yang sulit, akan tetapi guru lebih diutamakan berperan sebagai seorang akademisi yang akan memberikan pengalaman musik sesuai dengan kehidupan anak dalam keseharian mereka, yang dalam hal ini musik dijadikan sebagai media umum guna memberikan pengalaman siswa dalam musik (Yuni, 2017).

Berdasarkan studi pendahuluan yang dilakukan oleh peneliti di beberapa sekolah terhadap guru mengenai pendidikan seni musik, terdapat beberapa permasalahan terjadi yang diantaranya pendidikan seni khususnya seni musik menjadi pembelajaran minoritas. Guru hanya melaksanakan pembelajaran seni musik dengan cara bernyanyi tanpa adanya variasi pembelajaran. Guru berpandangan bahwa pendidikan seni musik hanya dapat berjalan optimal jika ada fasilitas yang menunjang yang dalam hal ini alat musik. Hal tersebut pernah di teliti oleh peneliti lain yang di dalam hasilnya dijelaskan bahwa hanya sedikit guru yang memiliki kompetensi dalam pendidikan seni musik musik. mereka yang sedikitnya menguasai unsur-unsur dasar musik adalah yang memiliki aktivitas musikal seperti bisa bernyanyi atau memainkan alat-alat musik. Kemampuan tersebut juga bukan hasil dari belajar di lembaga formal, akan tetapi mereka secara kebetulan terlahir dari keluarga seniman, atau sebelum terjun menjadi seorang guru mereka pernah terjun dari dunia seni atau pemain seni tradisi serta belajar secara otodidak dari teman pergaulannya (Julia, 2017). Dari kajian dan permasalahan yang telah di paparkan di atas maka perlu di ketahui bagaimana persepsi guru terhadap pendidikan seni musik, karena jika guru salah dalam mempersepsikan tentang bagaimana pendidikan seni musik di sekolah dasar dilaksanakan maka akan berdampak terhadap bagaimana cara guru dalam mengajar. Pengungkapan persepsi guru dapat dilakukan dengan sebuah penelitian yang fokus untuk mendeskripsikan suatu pendapat atau persepsi seorang guru. sebagaimana (Fahmi, 2020; Faudy, 2015) menjelaskan bahwa persepsi guru adalah proses seorang guru dalam menginterpretasikan, mengorganisasikan dan memberi makna terhadap stimulus yang berasal dari lingkungan dimana ia berada yakni berasal dari proses belajar dan pengalaman sehingga tercipta hubungan-hubungan yang diperoleh dengan menyimpulkan informasi dan menafsirkan pesan.

Tujuan diadakannya penelitian ini sebagaimana mengacu pada bahasan dan permasalahan diatas yakni menganalisis gambaran deskriptif tentang sejauh mana persepsi guru sekolah dasar terhadap pendidikan seni musik. Lebih dari itu pentingnya penelitian dilakukan yakni agar hasil dari penelitian dapat di manfaatkan oleh berbagai pihak untuk mengevaluasi atau menilai guna pengembangan yang lebih subtantif mengarah 

Akbar Maulana, Resa Respati, Epon Nur'aeni L, Muhammad Rijal Wahid Muharram

DOI: https://doi.org/10.31004/edukatif.v3i5.752

pada peningkatan kompetensi guru serta pendidikan. Adapun penelitian yang dilakukan tentu memiliki keunggulan dimana temuan-temuan di lapangan dapat di interpretasi berdasarkan gambaran statistik deskriptif yang mana hasil tersebut dapat memberikan tingkat persepsi guru sekolah dasar terhadap pendidikan seni musik.

\section{METODE PENELITIAN}

Dalam penelitian ini peneliti menggunakan metode survei, dimana Wimmer-Dominicik dalam (Morissan, 2018) mengemukakan bahwa penelitian survey dapat dibagi menjadi dua kategori yakni survei deskriptif (deskriptif survey) dan survei analisis (analytical survey). Dari penjelasan mengenai kategori tersebut, maka penelitian ini menggunakan metode survei deskriptif, dimana dijelaskan bahwa metode survei desktriptif memiliki upaya untuk menjelakan atau mencatat kondisi maupun sebuah sikap guna menjalankan apa yang telah terjadi pada saat ini (Morissan, 2018).

Metode survei digunakan untuk mendapatkan data dari tempat tertentu yang alamiah (bukan buatan), tetapi peneliti melakukan perlakuan dalam pengumpulan data, misalnya dengan mengedarkan kuesioner, test, wawancara terstruktur dan sebagainya (Sugiyono, 2016). Adapun penelitian survei dapat dilakukan berdasarkan langkah sebagai berikut.

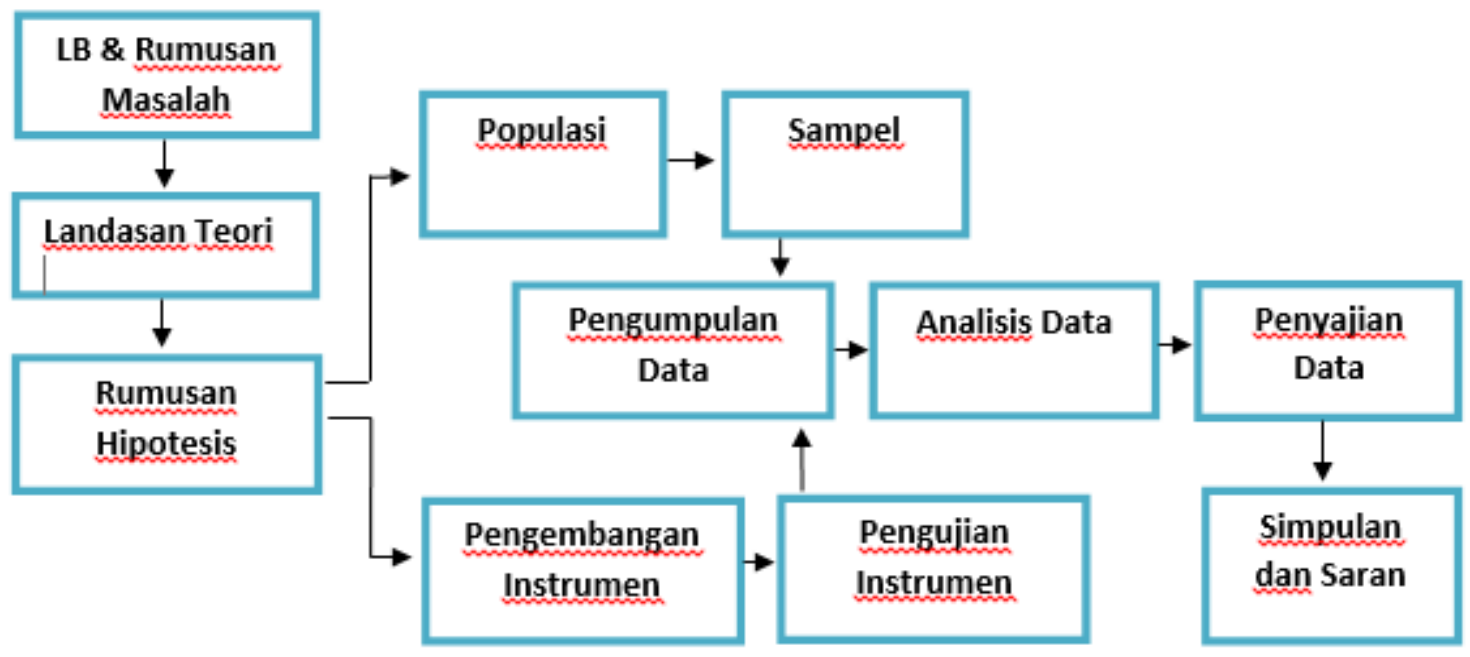

Gambar 1. Prosedur Penelitian Survei Kuantitatif

Penelitian ini menggunakan teknik simple random sampling yang merupakan teknik sampling probability. Menurut (Sudaryono, 2018) dikatakan simple (sederhana) karena pengambilan anggota sampel dari populasi dilakukan secara acak tanpa memerhatikan strata yang ada dalam populasi itu karena guru dalam penelitian persepsi ini berstatus homogen. Jumlah guru sekolah dasar yang berada di Wilayah kecamatan Rancabali kabupaten Bandung Jawa Barat sebanyak 212 guru untuk kemudian diambil 32 guru untuk di jadikan sampel. Instrumen penelitian yang digunakan berupa angket. Angket disusun untuk mengetahui tingkat persepsi guru dalam pendidikan seni musik di sekolah dasar meliputi aspek hakikat, mafaat dan pembelajaran dalam pendidikan di sekolah dasar.

Uji validitas instrumen dilakukan melalui proses uji validitas oleh dosen ahli. Angket yang digunakan memiliki nilai item reliability dan person reliability yang baik $(>0,7)$. Nilai validitas setiap item berdasarkan hasil analisis dinyatakan semua item yang digunakan sebagai angket juga valid karena nilai MNSQ, ZSTD dan, PT Measure Corr sudah memenuhi kriteria yang disyaratkan dalam pemodelan rasch. Item pernyataan dikatakan valid jika salah satu nilai dari Outfif MNSQ, ZSTD dan CORR memenuhi kriteria yang disyaratkan 
2052 Analisis Persepsi Guru Sekolah Dasar Terhadap Pendidikan Seni Musik Melalui Pendekatan Rasch ModelAkbar Maulana, Resa Respati, Epon Nur'aeni L, Muhammad Rijal Wahid Muharram

DOI: https://doi.org/10.31004/edukatif.v3i5.752

dalam Pemodelan Rasch. Nilai Outfit mean square (0,5 < MNSQ < 1,5), (-0,2 < ZSTD, 2.0), $(0,4<\mathrm{Pt}$ Measure Corr < 0,85). (Sumintono, B., \& Widhiarso, 2013).

\section{HASIL PENELITIAN}

Penelitian dilakukan dengan pengambilan data terhadap 32 guru dengan mengajukan 25 pernyataan dan mengunakan skala Likers $1-5(1=$ Sangat Setuju, $2=$ Setuju, $3=$ Netral, $4=$ Tidak Setuju, $5=$ Sangat Tidak Setuju). Pengolahan data yang pertama dilakukan untuk mengetahui secara umum mengenai instrument dan interaksi kecenderungan antar person berdasarkan table Summery Statistic. Dari gambar 2 tentang summary statistics maka dapat di dapat diperoleh informasi mengenai nilai person measure, nilai alpha Cronbach, nilai INFIT dan OUTFIT serta nilai separation. Pada person measure diproleh nilai 2.01 logit dimana nilai tersebut menunjukkan rata-rata nilai responden dalam instrumen pernyataan guru. Nilai rata-rata yang lebih dari logit 0.0 menunjukkan kecenderungan responden memilih Setuju dalam sebagaran item pernyataan. Pada nilai alpha cronbach (mengukur realiabilitas, yaitu interaksi antara responden dan item secara keseluruhan) didapat nilai 0.91 yang berarti bagus. Pada INFIT dan OUTFIT MNSQ pada tabel person nilai rata-ratanya secara berurutan diketahui 1.07 dan 1.00 (nilai idealnya adalah 1.00 maka semakin mendekati 1.00 semakin baik); untuk OUTFIT ZSTD, nilai rata-rata pada tabel person adalah 0.04 dan - 0.15 dimana nilai idealnya adalah 0.0 (semakin mendekati nilai 0.0 maka kualitas interaksi person dalam menjawab semakin baik). Demikian pula untuk tabel item. Untuk pengelompokkan responden dan item peneliti melihat berdasarkan nilai separation. Dikethui Nilai separation pada person adalah 2.76. Pengelompokkan secara lebih teliti disebut dengan pemisahan strata berdasarkan rumus penghitungan $[(4 \times 2.76) / 3=3.68$ artinya hanya terdapat tiga kelompok responden dalam penelitian ini.

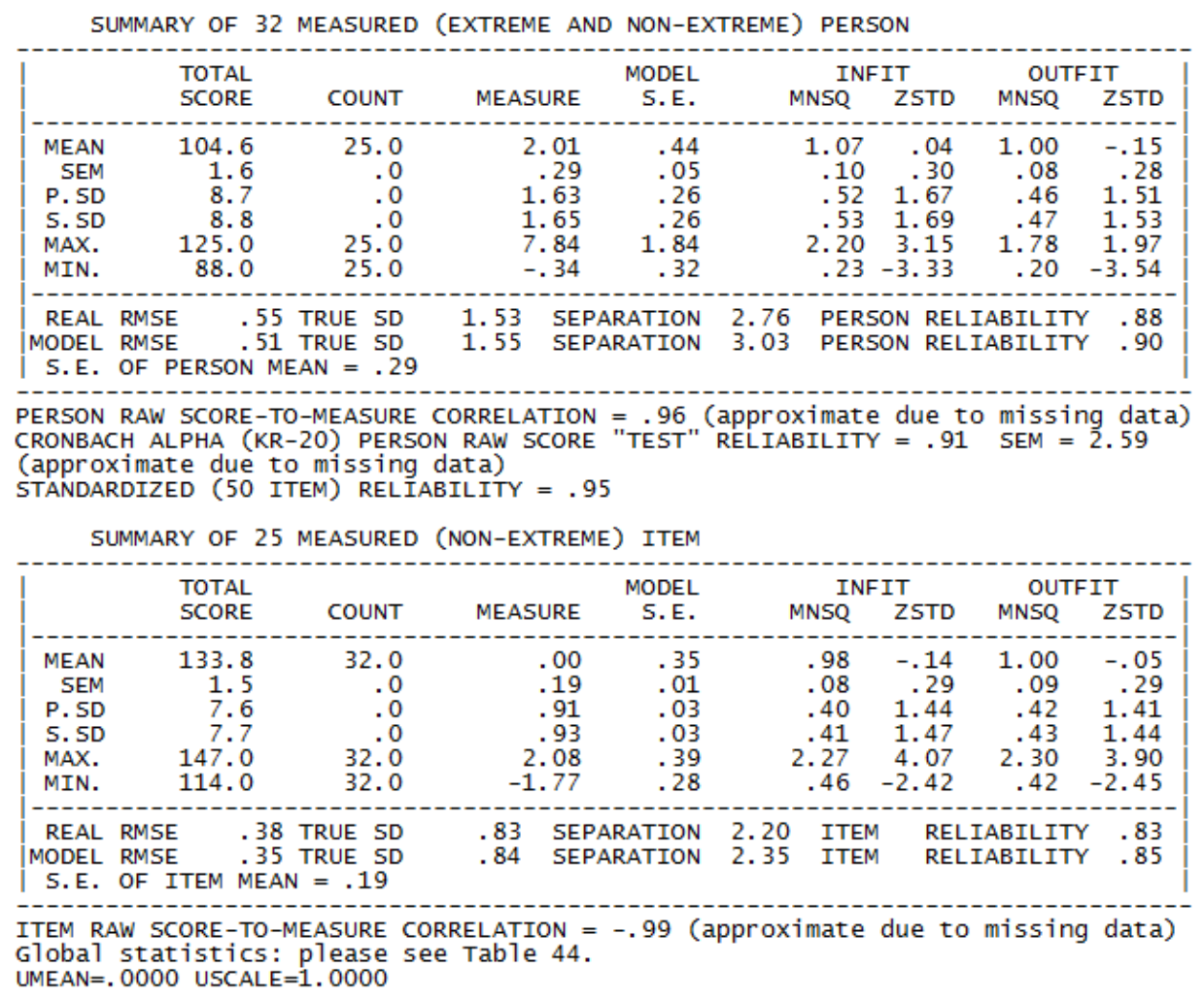

\section{Gambar 2. Summary Statistics}

Menganalisis lebih dalam hasil data yang diperoleh mengenai persepsi guru terhadap pendidikan seni musik di sekolah dasar melalui person statistic dan item statistic. Berikut ini data person statistic hasil 

Akbar Maulana, Resa Respati, Epon Nur'aeni L, Muhammad Rijal Wahid Muharram

DOI: https://doi.org/10.31004/edukatif.v3i5.752

pengolahan menggunakan winstep. Berdasarkan gambar 3 diperoleh informasi bahwa responden dengan tingkat abilitas tinggi di dapat oleh G31. Total skor yang diperoleh yaitu 125, tingkat abilitas menjelaskan bahwa guru tersebut memiliki persepsi yang lebih baik dibanding guru yang lainnya, hal tersebut didasarkan pada score yang diperoleh guru saat mengisi angket. Sedangkan untuk responden dengan tingkat abilitas terendah di dapat oleh G13. Total skor yang diperoleh adalah 88 .

PERSON STATISTICS: ENTRY ORDER

\begin{tabular}{|c|c|c|c|c|c|c|c|c|c|c|c|c|c|}
\hline $\begin{array}{l}\text { ENTRY } \\
\text { NUMBER }\end{array}$ & $\begin{array}{l}\text { TOTAL } \\
\text { SCORE }\end{array}$ & $\begin{array}{l}\text { TOTAL } \\
\text { COUNT }\end{array}$ & MEASURE & $\begin{array}{l}\text { MODEL } \\
\text { S.E. }\end{array}$ & $\begin{array}{l}\text { IN } \\
\text { MNSQ }\end{array}$ & $\begin{array}{l}\text { IFIT } \\
\text { ZSTD }\end{array}$ & \begin{tabular}{|c|} 
OUTT \\
MNSQ
\end{tabular} & $\begin{array}{l}\text { FIT } \\
\text { ZSTD }\end{array}$ & $\begin{array}{l}\text { PTMEAS } \\
\text { CORR. }\end{array}$ & $\begin{array}{l}\text { JR-AL } \\
\text { EXP. }\end{array}$ & $\begin{array}{r}\text { EXACT } \\
\text { OBS\% }\end{array}$ & $\begin{array}{r}\text { MATCH } \\
\text { EXP\% }\end{array}$ & PERSON \\
\hline $\begin{array}{r}1 \\
2 \\
3 \\
4 \\
5 \\
6 \\
7 \\
8 \\
9 \\
10 \\
11 \\
12 \\
13 \\
14 \\
15 \\
16 \\
17 \\
18 \\
19 \\
20 \\
21 \\
22 \\
23 \\
24 \\
25 \\
26 \\
27 \\
28 \\
29 \\
30 \\
31 \\
32\end{array}$ & $\begin{array}{r}102 \\
119 \\
109 \\
101 \\
105 \\
100 \\
100 \\
107 \\
103 \\
99 \\
102 \\
99 \\
88 \\
111 \\
100 \\
110 \\
93 \\
121 \\
106 \\
106 \\
96 \\
117 \\
101 \\
97 \\
116 \\
116 \\
102 \\
107 \\
95 \\
91 \\
125 \\
102\end{array}$ & $\begin{array}{l}25 \\
25 \\
25 \\
25 \\
25 \\
25 \\
25 \\
25 \\
25 \\
25 \\
25 \\
25 \\
25 \\
25 \\
25 \\
25 \\
25 \\
25 \\
25 \\
25 \\
25 \\
25 \\
25 \\
25 \\
25 \\
25 \\
25 \\
25 \\
25 \\
25 \\
25 \\
25\end{array}$ & $\begin{array}{l}1.45 \\
4.38 \\
2.54 \\
1.30 \\
1.91 \\
1.16 \\
1.16 \\
2.23 \\
1.61 \\
1.01 \\
1.45 \\
1.01 \\
-.34 \\
2.86 \\
1.16 \\
2.70 \\
.22 \\
4.95 \\
2.07 \\
2.07 \\
.60 \\
3.93 \\
1.30 \\
.73 \\
3.73 \\
3.73 \\
1.45 \\
2.23 \\
.47 \\
-.01 \\
7.84 \\
1.45\end{array}$ & $\begin{array}{l}.39 \\
.50 \\
.40 \\
.39 \\
.39 \\
.38 \\
.38 \\
.40 \\
.39 \\
.38 \\
.39 \\
.38 \\
.32 \\
.40 \\
.38 \\
.40 \\
.35 \\
.57 \\
.39 \\
.39 \\
.36 \\
.45 \\
.39 \\
.37 \\
.44 \\
.44 \\
.39 \\
.40 \\
.36 \\
.34 \\
1.84 \\
.39\end{array}$ & $\begin{array}{r}.55 \\
2.20 \\
.94 \\
1.96 \\
1.53 \\
1.40 \\
1.84 \\
.87 \\
1.22 \\
1.19 \\
.25 \\
.37 \\
.55 \\
.85 \\
.75 \\
1.03 \\
1.32 \\
1.90 \\
.64 \\
1.33 \\
.73 \\
1.42 \\
.23 \\
.40 \\
.99 \\
1.41 \\
.71 \\
1.22 \\
.79 \\
.68 \\
\text { MAXI } \\
1.84\end{array}$ & \begin{tabular}{r|}
-1.55 \\
3.15 \\
-.18 \\
2.37 \\
1.62 \\
1.17 \\
2.11 \\
-.41 \\
.75 \\
.63 \\
-3.31 \\
-2.38 \\
-1.83 \\
-.60 \\
-.70 \\
.20 \\
1.03 \\
2.00 \\
-1.35 \\
1.13 \\
-.78 \\
1.58 \\
-3.33 \\
-2.24 \\
.03 \\
1.62 \\
-.88 \\
.85 \\
-.57 \\
-1.09 \\
$M M M$ \\
2.16
\end{tabular} & $\begin{array}{r}.54 \\
1.78 \\
.93 \\
1.78 \\
1.43 \\
1.33 \\
1.76 \\
.82 \\
1.08 \\
1.13 \\
.22 \\
.32 \\
.56 \\
.91 \\
.64 \\
1.04 \\
1.34 \\
1.08 \\
.64 \\
1.28 \\
.69 \\
1.55 \\
.20 \\
.42 \\
1.10 \\
1.33 \\
.70 \\
1.23 \\
.72 \\
.64 \\
E A 5 U R E \\
1.74\end{array}$ & \begin{tabular}{r|}
-1.55 \\
1.66 \\
-.18 \\
1.97 \\
1.37 \\
.97 \\
1.91 \\
-.60 \\
.34 \\
.47 \\
-3.45 \\
-2.58 \\
-1.61 \\
-.32 \\
-1.06 \\
.25 \\
1.02 \\
.33 \\
-1.36 \\
.98 \\
-.89 \\
1.57 \\
-3.54 \\
-1.99 \\
.42 \\
1.13 \\
-.88 \\
.87 \\
-.79 \\
-1.17 \\
1.93
\end{tabular} & $\begin{array}{l}. .11 \\
.13 \\
.22 \\
.82 \\
.81 \\
.79 \\
.80 \\
.16 \\
.88 \\
.45 \\
.53 \\
.07 \\
.48 \\
.38 \\
.44 \\
.45 \\
.21 \\
.48 \\
.37 \\
.20 \\
.03 \\
.23 \\
.40 \\
.57 \\
.31 \\
.51 \\
.46 \\
.59 \\
.08 \\
.36 \\
.00 \\
.16\end{array}$ & $\begin{array}{l}.42 \\
.36 \\
.41 \\
.43 \\
.42 \\
.43 \\
.43 \\
.42 \\
.42 \\
.44 \\
.42 \\
.44 \\
.50 \\
.41 \\
.43 \\
.41 \\
.48 \\
.32 \\
.42 \\
.42 \\
.46 \\
.38 \\
.43 \\
.45 \\
.39 \\
.39 \\
.42 \\
.42 \\
.46 \\
.49 \\
.00 \\
.42\end{array}$ & $\begin{array}{r}84.0 \\
76.0 \\
64.0 \\
36.0 \\
56.0 \\
52.0 \\
48.0 \\
72.0 \\
60.0 \\
72.0 \\
92.0 \\
88.0 \\
68.0 \\
68.0 \\
80.0 \\
60.0 \\
64.0 \\
92.0 \\
72.0 \\
64.0 \\
76.0 \\
68.0 \\
96.0 \\
88.0 \\
72.0 \\
64.0 \\
68.0 \\
64.0 \\
68.0 \\
68.0 \\
100.0 \\
56.0\end{array}$ & $\begin{array}{r}69.7 \\
78.3 \\
64.7 \\
70.2 \\
68.2 \\
70.1 \\
70.1 \\
66.1 \\
69.7 \\
70.5 \\
69.7 \\
70.5 \\
58.2 \\
64.3 \\
70.1 \\
64.2 \\
64.5 \\
84.4 \\
67.2 \\
67.2 \\
69.7 \\
72.1 \\
70.2 \\
70.3 \\
69.8 \\
69.8 \\
69.7 \\
66.1 \\
68.2 \\
62.6 \\
100.0 \\
69.7\end{array}$ & $\begin{array}{l}\text { G1 } \\
\text { G2 } \\
\text { G3 } \\
\text { G4 } \\
\text { G5 } \\
\text { G6 } \\
\text { G7 } \\
\text { G8 } \\
\text { G9 } \\
\text { G10 } \\
\text { G11 } \\
\text { G12 } \\
\text { G13 } \\
\text { G14 } \\
\text { G15 } \\
\text { G16 } \\
\text { G17 } \\
\text { G18 } \\
\text { G19 } \\
\text { G20 } \\
\text { G21 } \\
\text { G22 } \\
\text { G23 } \\
\text { G24 } \\
\text { G25 } \\
\text { G26 } \\
\text { G27 } \\
\text { G28 } \\
\text { G29 } \\
\text { G30 } \\
\text { G31 } \\
\text { G32 }\end{array}$ \\
\hline $\begin{array}{l}\text { MEAN } \\
\text { P.SD }\end{array}$ & $\begin{array}{r}104.6 \\
8.7\end{array}$ & $\begin{array}{r}25.0 \\
.0\end{array}$ & $\begin{array}{l}2.01 \\
1.63\end{array}$ & .44 & $\begin{array}{r}1.07 \\
.52\end{array}$ & \begin{tabular}{r|}
.0 \\
1.7
\end{tabular} & $\begin{array}{r}1.00 \\
.46\end{array}$ & $\begin{array}{c}-.2 \\
1.5\end{array}$ & & & $\begin{array}{l}69.5 \\
13.2\end{array}$ & $\begin{array}{r}68.9 \\
4.5\end{array}$ & \\
\hline
\end{tabular}

Gambar 3. Person Statistics

Berdasarkan gambar 4 diperoleh informasi bahwa item dengan kode P19 adalah pernyataan yang paling banyak tidak setuju dan pernyataan yang paling banyak disetujui adalah soal P4. Pernyataan P19 berisi "Pembelajaran dalam pendidikan seni musik memiliki sasaran keberhasilan" ini berarti bahwa guru sebagian besar tidak setuju bahwa pendidikan seni musik yang terlaksana saat ini memiliki sasaran keberhasilan. Pernyataan P4 berisi "Peserta didik dapat mengekspresikan dirinya melalui kegiatan bermusik" ini berarti bahwa guru sebagian besar setuju bahwa dalam kegiatan bermusik siswa dapat mengekspresikan dirinya. 
2054 Analisis Persepsi Guru Sekolah Dasar Terhadap Pendidikan Seni Musik Melalui Pendekatan Rasch ModelAkbar Maulana, Resa Respati, Epon Nur'aeni L, Muhammad Rijal Wahid Muharram

DOI: https://doi.org/10.31004/edukatif.v3i5.752

ITEM STATISTICS: ENTRY ORDER

\begin{tabular}{|c|c|c|c|c|c|c|c|c|c|c|c|c|c|}
\hline $\begin{array}{l}\text { ENTRY } \\
\text { NUMBER }\end{array}$ & $\begin{array}{l}\text { TOTAL } \\
\text { SCORE }\end{array}$ & $\begin{array}{l}\text { TOTAL } \\
\text { COUNT }\end{array}$ & MEASURE & $\begin{array}{l}\text { MODEL } \\
\text { S.E. }\end{array}$ & MNSQ & $\begin{array}{l}\text { NFIT } \\
\text { ZSTD }\end{array}$ & \begin{tabular}{|c} 
OUT \\
MNSQ
\end{tabular} & $\begin{array}{l}\text { FIT } \\
\text { ZSTD }\end{array}$ & $\begin{array}{l}\text { | PTMEAS } \\
\text { CORR. }\end{array}$ & $\begin{array}{l}\text { UR-AL } \\
\text { EXP. }\end{array}$ & \begin{tabular}{|r} 
EXACT \\
OBS\%
\end{tabular} & $\begin{array}{r}\text { MATCH } \\
\text { EXP\% }\end{array}$ & ITEM \\
\hline $\begin{array}{r}1 \\
2 \\
3 \\
4 \\
5 \\
6 \\
7 \\
8 \\
9 \\
10 \\
11 \\
12 \\
13 \\
14 \\
15 \\
16 \\
17 \\
18 \\
19 \\
20 \\
21 \\
22 \\
23 \\
24 \\
25\end{array}$ & $\begin{array}{l}139 \\
136 \\
143 \\
147 \\
141 \\
137 \\
139 \\
139 \\
132 \\
127 \\
118 \\
128 \\
135 \\
134 \\
145 \\
135 \\
140 \\
126 \\
114 \\
132 \\
128 \\
129 \\
132 \\
133 \\
137\end{array}$ & $\begin{array}{l}32 \\
32 \\
32 \\
32 \\
32 \\
32 \\
32 \\
32 \\
32 \\
32 \\
32 \\
32 \\
32 \\
32 \\
32 \\
32 \\
32 \\
32 \\
32 \\
32 \\
32 \\
32 \\
32 \\
32 \\
32\end{array}$ & $\begin{array}{r}-.62 \\
-.21 \\
-1.18 \\
-1.77 \\
-.90 \\
-.35 \\
-.62 \\
-.62 \\
.30 \\
.88 \\
1.75 \\
.77 \\
-.08 \\
.05 \\
-1.47 \\
-.08 \\
-.76 \\
.99 \\
2.08 \\
.30 \\
.77 \\
.66 \\
.30 \\
.18 \\
-.35\end{array}$ & $\begin{array}{l}.37 \\
.37 \\
.38 \\
.39 \\
.37 \\
.37 \\
.37 \\
.37 \\
.35 \\
.33 \\
.29 \\
.33 \\
.36 \\
.36 \\
.38 \\
.36 \\
.37 \\
.32 \\
.28 \\
.35 \\
.33 \\
.34 \\
.35 \\
.36 \\
.37\end{array}$ & $\begin{array}{r}1.63 \\
.50 \\
.75 \\
.68 \\
.85 \\
1.33 \\
1.30 \\
.46 \\
1.00 \\
.93 \\
1.21 \\
1.32 \\
.52 \\
1.04 \\
.98 \\
.85 \\
.94 \\
1.44 \\
2.27 \\
.49 \\
.87 \\
.87 \\
.89 \\
.71 \\
.62\end{array}$ & $\begin{array}{r}2.04 \\
-2.02 \\
-1.09 \\
-1.62 \\
-.55 \\
1.14 \\
1.09 \\
-2.42 \\
.10 \\
-.14 \\
.89 \\
1.09 \\
-1.84 \\
.23 \\
.00 \\
-.42 \\
-.15 \\
1.45 \\
4.07 \\
-1.98 \\
-.37 \\
-.36 \\
-.26 \\
-.95 \\
-1.45\end{array}$ & $\begin{array}{r}1.58 \\
.48 \\
.78 \\
.64 \\
.77 \\
1.28 \\
1.27 \\
.42 \\
.90 \\
1.13 \\
1.34 \\
1.41 \\
.50 \\
1.04 \\
1.12 \\
.82 \\
1.00 \\
1.51 \\
2.30 \\
.47 \\
.87 \\
.90 \\
1.00 \\
.74 \\
.68\end{array}$ & $\begin{array}{r}1.79 \\
-2.08 \\
-.67 \\
-1.01 \\
-.74 \\
.97 \\
.95 \\
-2.45 \\
-.25 \\
.52 \\
1.24 \\
1.30 \\
-1.96 \\
.22 \\
.46 \\
-.52 \\
.09 \\
1.59 \\
3.90 \\
-2.08 \\
-.35 \\
-.23 \\
.11 \\
-.85 \\
-1.13\end{array}$ & $\begin{array}{l}.44 \\
.70 \\
.53 \\
.56 \\
.65 \\
.46 \\
.50 \\
.69 \\
.73 \\
.48 \\
.48 \\
.57 \\
.72 \\
.58 \\
.40 \\
.62 \\
.42 \\
.56 \\
.38 \\
.74 \\
.62 \\
.50 \\
.52 \\
.58 \\
.56\end{array}$ & $\begin{array}{l}.52 \\
.54 \\
.48 \\
.43 \\
.50 \\
.54 \\
.52 \\
.52 \\
.56 \\
.58 \\
.60 \\
.57 \\
.55 \\
.55 \\
.46 \\
.55 \\
.51 \\
.58 \\
.62 \\
.56 \\
.57 \\
.57 \\
.56 \\
.56 \\
.54\end{array}$ & $\begin{array}{l}48.4 \\
90.3 \\
77.4 \\
80.6 \\
67.7 \\
64.5 \\
61.3 \\
80.6 \\
74.2 \\
74.2 \\
54.8 \\
61.3 \\
83.9 \\
67.7 \\
61.3 \\
71.0 \\
71.0 \\
54.8 \\
25.8 \\
83.9 \\
64.5 \\
74.2 \\
80.6 \\
83.9 \\
80.6\end{array}$ & $\begin{array}{l}70.6 \\
71.7 \\
68.9 \\
68.5 \\
69.5 \\
71.4 \\
70.6 \\
70.6 \\
71.1 \\
67.2 \\
58.2 \\
67.7 \\
72.0 \\
72.0 \\
68.1 \\
72.0 \\
70.0 \\
66.2 \\
54.3 \\
71.1 \\
67.7 \\
68.9 \\
71.1 \\
71.9 \\
71.4\end{array}$ & $\begin{array}{l}\text { P1 } \\
\text { P2 } \\
\text { P3 } \\
\text { P4 } \\
\text { P5 } \\
\text { P6 } \\
\text { P7 } \\
\text { P8 } \\
\text { P9 } \\
\text { P10 } \\
\text { P11 } \\
\text { P12 } \\
\text { P13 } \\
\text { P14 } \\
\text { P15 } \\
\text { P16 } \\
\text { P17 } \\
\text { P18 } \\
\text { P19 } \\
\text { P20 } \\
\text { P21 } \\
\text { P22 } \\
\text { P23 } \\
\text { P24 } \\
\text { P25 }\end{array}$ \\
\hline $\begin{array}{l}\text { MEAN } \\
\text { P.SD }\end{array}$ & $\begin{array}{r}133.8 \\
7.6\end{array}$ & $\begin{array}{r}32.0 \\
.0\end{array}$ & $\begin{array}{l}.00 \\
.91\end{array}$ & .35 & $\begin{array}{l}.98 \\
.40\end{array}$ & $\begin{array}{l}-.1 \\
1.4\end{array}$ & $\begin{array}{r}1.00 \\
.42\end{array}$ & $\begin{array}{r}.0 \\
1.4\end{array}$ & & & $\begin{array}{l}69.5 \\
13.7\end{array}$ & $\begin{array}{r}68.9 \\
4.1\end{array}$ & \\
\hline
\end{tabular}

Gambar 4. Item Statistics

Selanjutnya tingkat interaksi dan keterhubungan antara person dengan item dapat dianalisis berdasarkan diagram variable wright maps, dalam diagram ini jangkauan item pernyataan yang dapat dijawab oleh guru. Pada gambar 5 disajikan mengenai jangkauan soal yang dapat dilaksanakan oleh guru. Guru dengan kode G31, G18, G2, G22, G25, G26, G14, G16, G3, G28, G8, G19 dan G20 menyetujui hampir seluruh aspek pendidikan seni musik di sekolah dasar. Guru yang lainnya G5, dan G9 secara keseluruhan memberikan persepsi positif kecuali pada pernyataan P19 yang memberikan persepsi tidak baik yaitu berkaitan dengan pembelajaran dalam pendidikan seni musik. Guru lainnya G1, G11, G27, G32, G23, G4, G15, G6, G7, G10, G12 secara keseluruhan dapat memberikan persepsi posotof, akan tetapi pada pernyataan P19 dan P11 belum memberikan persepsi positif yaitu berkaitan dengan pembelajaran dalam pendidikan seni musik serta manfaat pendidikan seni musk. Guru lainnya G21, G24, G29 Secara keseluruhan belum memberikan persepsi positif dalam pernyataan P19, P11, P18, P10, P12, P21, P22. Guru lainnya G17 belum memberikan persepsi posotif dalam pernyataan P19, P11, P18, P10, P12, P21, P22, P20, P23, P9. Guru lainnya G30 belum memberikan perspsi positif dalam pernyataan P19, P11, P18, P10, P12, P21, P22, P20, P23, P9 dan P24. Guru lainnya G13 belum memberikan persepsi positif dalam pernyataan P19, P11, P18, P10, P12, P21, P22, P20, P23, P9, P24 dan P2. Posisi person yang sejajar pada garis yang sama seperti (G28, G8) (G25, G26) (G19, G20) (G11, G1, G27, G32) (G23, G4) (G15, G6, G7) (G10, G12) dan (G21, G24) menunjukan tingkat persepsi yang setara. Secara keseluruhan Nilai $6.0<$ logit $<-0,1$ menunjukan bahwa persepsi guru dalam pendidikan seni musik sudah positif, karena kebanyakan pertanyaan di setujui oleh sebaran guru kecuali pada item pernyataan dengan kode P19 dan P11. 
2055 Analisis Persepsi Guru Sekolah Dasar Terhadap Pendidikan Seni Musik Melalui Pendekatan Rasch ModelAkbar Maulana, Resa Respati, Epon Nur'aeni L, Muhammad Rijal Wahid Muharram

DOI: https://doi.org/10.31004/edukatif.v3i5.752

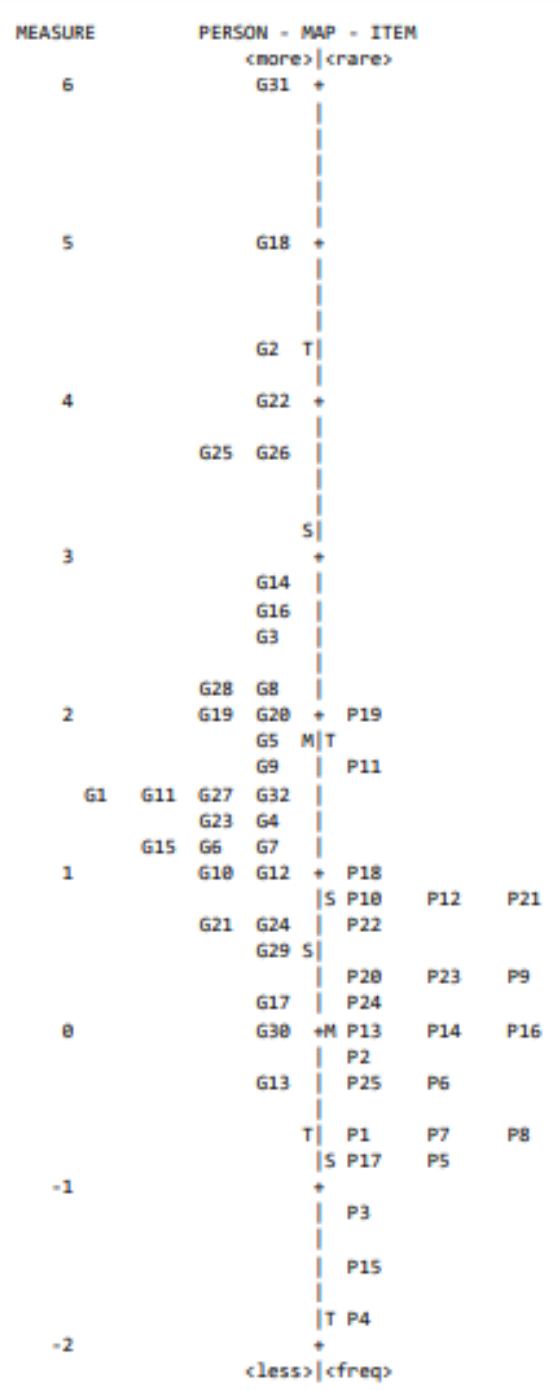

Gambar 5. Variable Wright Maps

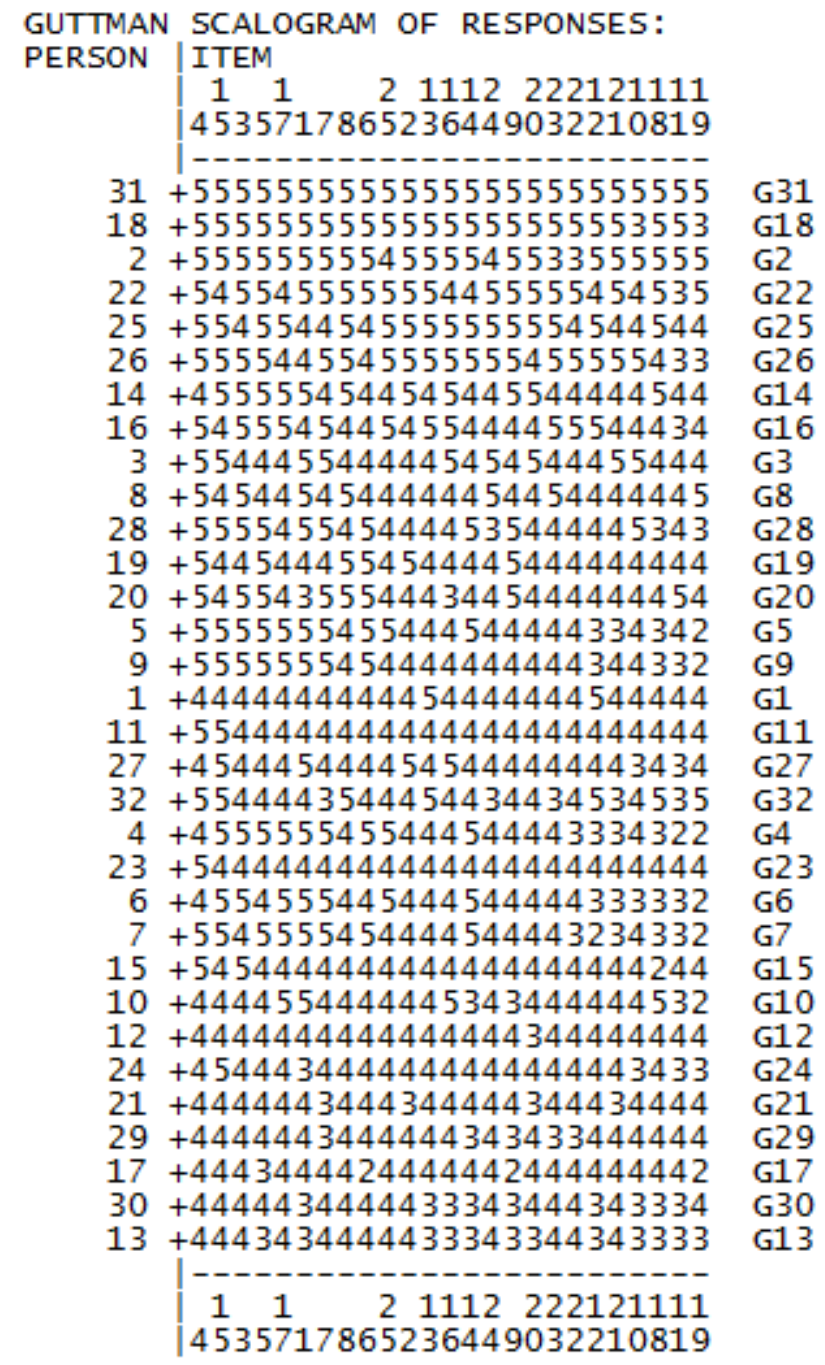

Gambar 6. Scalograms

Selanjutnya pengolahan hasil jawaban angket oleh Rasch Model disajikan melalui model Gutman Scalograms seperti pada Gambar 6, yaitu mengorganisasikan person atau guru berdasarkan tingkat abilitas tinggi-rendah. Berdasarkan pada Gambar 6 dianalisis secara vertikal yaitu item ketimpangan pelaksanaan kompetensi guru dalam satu baris terletak pada item 25, 24, 23, 20 dan 9. Kemampuan rata-rata pada item urutan 25 yang dilakukan guru menunjukan setuju akan tetapi guru dengan kode G5, G9, G4, G6, G7, G10, G17 tidak setuju, ini berarti pada guru tersebut terdapat perbedaan persepsi yang signifikan. Item 25 berkenaan dengan pemahaman guru tentang evaluasi yang menyentuh ranah kognitif, psikomotor dan afektif dalam pembelajaran pendidikan seni musik. Kemampuan rata-rata pada item urutan 24 yang dilakukan menunjukan setuju, akan tetapi guru dengan kode G4 tidak setuju, ini berarti terdapat perbedaan persepsi yang signifikan. Item 24 bekenaan dengan pemahaman guru tentang penggunaan beragam media dalam pembelajaran seni musik. Kemampuan rata-rata pada item urutan 23 yang dilakukan guru menunjukan setuju, akan tetapi guru dengan kode G15 tidak setuju, ini berarti pada guru tersebut terdapat perbedaan persepsi yang signifikan. Item 23 berkenaan dengan pemahaman guru tentang materi tanda tempo, tangga nada serta interval nada musik di sekolah dasar. Kemampuan rata-rata pada item urutan 20 yang dilakukan menunjukan setuju, akan tetapi guru dengan kode G7 tidak setuju, ini berarti pada guru tersebut terdapat perbedaan persepsi yang signifikan. Item 20 berkenaan dengan pembelajaran dalam pendidikan seni musik menggunakan berbagai 
2056 Analisis Persepsi Guru Sekolah Dasar Terhadap Pendidikan Seni Musik Melalui Pendekatan Rasch ModelAkbar Maulana, Resa Respati, Epon Nur'aeni L, Muhammad Rijal Wahid Muharram

DOI: https://doi.org/10.31004/edukatif.v3i5.752

metode pembelajaran musik. Kemampuan rata-rata pada item urutan 9 yang dilakukan guru menunjukan setuju, akan tetapi guru dengan kode G17 tidak setuju, ini berarti pada guru tersebut terdapat perbedaan persepsi yang signifikan. Item 9 berkenaan dengan persepsi tentang bermain musik dapat memberikan ketenangan bagi peserta didik.

Persepsi guru sekolah dasar terhadap pendidikan seni musik dianalisis tingkat persentase persepsi berdasarkan jumlah skor yang diperoleh guru setelah mengisi pernyataan. Pada Tabel 1. Menggambarkan persepsi guru, secara keseluruhan $83.65 \%$ guru memberikan persepsi baik dalam pendidikan seni musik di sekolah dasar.

Tabel 1. Persepsi terhadap pendidikan seni musik di sekolah dasar oleh guru.

\begin{tabular}{|c|c|c|}
\hline Guru & Total Score & Persepsi Guru \\
\hline G1 & 102 & $81.6 \%$ \\
\hline G2 & 119 & $95.2 \%$ \\
\hline G3 & 109 & $87.2 \%$ \\
\hline G4 & 101 & $80.8 \%$ \\
\hline G5 & 105 & $84 \%$ \\
\hline G6 & 100 & $80 \%$ \\
\hline G7 & 100 & $80 \%$ \\
\hline G8 & 107 & $85.6 \%$ \\
\hline G9 & 103 & $82.4 \%$ \\
\hline G10 & 99 & $79.2 \%$ \\
\hline G11 & 102 & $81.6 \%$ \\
\hline G12 & 99 & $79.2 \%$ \\
\hline G13 & 88 & $70.4 \%$ \\
\hline G14 & 111 & $88.8 \%$ \\
\hline G15 & 100 & $80 \%$ \\
\hline G16 & 110 & $88 \%$ \\
\hline G17 & 93 & $74.4 \%$ \\
\hline G18 & 121 & $96.8 \%$ \\
\hline G19 & 106 & $84.8 \%$ \\
\hline G20 & 106 & $84.8 \%$ \\
\hline G21 & 96 & $76.8 \%$ \\
\hline G22 & 117 & $93.6 \%$ \\
\hline G23 & 101 & $80.8 \%$ \\
\hline G24 & 97 & $77.6 \%$ \\
\hline G25 & 116 & $92.8 \%$ \\
\hline G26 & 116 & $92.8 \%$ \\
\hline G27 & 102 & $81.6 \%$ \\
\hline G28 & 107 & $85.6 \%$ \\
\hline G29 & 95 & $76 \%$ \\
\hline G30 & 91 & $72.8 \%$ \\
\hline G31 & 125 & $100 \%$ \\
\hline G32 & 102 & $81.6 \%$ \\
\hline Total Rata-rata & 104 & $83.65 \%$ \\
\hline
\end{tabular}

Perhitungan persentase persepsi guru berdasarkan analisis mengunakan winstep mengacu pada skor yang diperoleh guru. Cara perhitungan persentase pelaksanaan oleh setiap guru adalah dengan rumus $A B x$ 100 dimana A adalah skor yang diperoleh guru dan B adalah persepsi guru: Skor maksimal diketahui dari jumlah item pernyataan dikali 4 ( $($ item x 4). 
2057 Analisis Persepsi Guru Sekolah Dasar Terhadap Pendidikan Seni Musik Melalui Pendekatan Rasch ModelAkbar Maulana, Resa Respati, Epon Nur'aeni L, Muhammad Rijal Wahid Muharram

DOI: https://doi.org/10.31004/edukatif.v3i5.752

\section{PEMBAHASAN}

Pendidikan seni musik memiliki titik tolak dari berbagai asumsi yang ada seperti yang dinyatakan sebelumnya oleh Ki Hajar Dewantara dalam (Sinaga, 2009) "Musik merupakan salah satu faktor penentu dalam membentuk kepribadian anak". Dalam hal ini pendidikan seni di sekolah, dapat dijadikan sebagai dasar pendidikan dalam membentuk jiwa dan kepribadian (berakhlak). Arti lainnya yaitu bahwa kesenian merupakan elemen yang esensial dalam pembentukan watak setiap individu dan faktor yang mendasari setiap penciptaan karya seni. Pendidikan seni musik lebih menekankan pada pemberian pengalaman seni musik, yang nantinya akan melahirkan kemampuan untuk memanfaatkan seni musik pada kehidupan sehari hari. Dalam hal ini guru memiliki tugas untuk memahami pendidikan seni musik sebagaimana yang di jelaskan oleh (Yuni, 2017) bahwa guru tidak harus menjadi sebuah pakar dalam bidang seni musik akan tetapi disini guru memiliki tanggung jawab untuk memberikan pengalaman musik sesuai dengan kehidupan anak dalam keseharian.

Dari data yang di dapatkan hasil bahwa persepsi guru di sekolah dasar khususnya di kecamatan Rancabali kabupaten Bandung Jawa barat memiliki tingkat persepsi yang positif atau dalam hal ini guru memiliki pandangan yang baik dalam pendidikan seni musik. Hal tersebut dapat dilihat dari hasil pengolahan rasch model terutama dalam gambar Summary Statistics dimana terdapat nilai 2.01 logit yang berarti menunjukkan kecenderungan responden memilih Setuju dalam sebaran item pernyataan. Maksud dari setuju dalam angket tersebut adalah guru menyetujui konsep ideal yang harus dipahami oleh guru dalam pendidikan seni musik yang mana secara keseluruhan guru memiliki persepsi positif dalam aspek hakikat, manfaat dan pembelajaran dalam pendidikan seni musik. Data tersebut di perkuat dengan melihat table 1 dimana rata-rata setiap guru memiliki persepsi positif diatas $70 \%$ dengan rata-rata keseluruhan guru memberikan persepsi positif sebesar $83.65 \%$ dalam aspek hakikat pendidikan seni muik, manfaat pendidikan seni musik dan pembelajaran dalam pendidikan seni musik.

Penelitian yang dilakukan memiliki pertentangan dengan penelitian yang dilakukan sebelumnya oleh (Kukuh Prabawa et al., 2021) yang menjelaskan bahwa proses penyampaian pendidikan seni musik oleh guru masih dilakukan secara setengah-setengah yang berarti bahwa penyampaian pendidikan seni musik oleh guru belum menunjang sepenuhnya beberapa pengalaman dan kemampuan-kemampuan peserta didik dalam berekspresi, berapresiasi, berkreasi, harmoni, estetika, pembelajaran serta belum memperhatikan karakteristik dan tingkat perkembangan individual peserta didik. Selain itu penelitian yang dilakukan oleh (Afriadi, Putra; Aulia, 2019) menyebutkan bahwa pendidikan seni musik belum mampu memberikan kebebasan dan kematangan personal sebagai subjektivitas. Yang mana salah satu penyebabnya yakni kurang adanya usaha untuk menumbuhkan rasa kesadaran diri serta tanggung jawab yang tinggi pada individu siswa. Terlihat dari pendidik yang masih terlalu mendominasi seperti dalam pemilihan materi maupun penentuan lagu yang disampaikan masih tergantung pada pendidik sendiri, belum menyesuaikan dengan kondisi dan rata-rata potensi peserta didik. Selain itu, refleksi dan sistem evaluasi pembelajaran juga masih ditentukan oleh pendidik itu sendiri, belum didasarkan pada karakteristik pribadi peserta didik. Berbagai penelitian yang dilakukan tentang pendidikan seni musik dapat menjadi sebuah kajian yang selanjutnya dapat dimanfaatkan untuk kemajuan ilmu pengetahuan, sebagaimana hasil penelitian tentang persepsi guru sekolah dasar terhadap pendidikan seni musik, dimana menunjukan bahwa dari sampel yang diteliti terdapat $83.65 \%$ guru sekolah dasar. yang memiliki persepsi positif terhadap pendidikan seni musik.

\section{KESIMPULAN}

Berdasarkan hasil penelitian yang dilakukan bahwa sebagian besar persepsi guru terhadap pendidikan seni musik di sekolah dasar pada kecamatan Rancabali, kabupaten bandung, Jawa Barat menunjukan tingkat persepsi yang baik dengan nilai $83.65 \%$, karena sudah mengaitkan setiap kegiatan pembelajaran berdasarkan 
2058 Analisis Persepsi Guru Sekolah Dasar Terhadap Pendidikan Seni Musik Melalui Pendekatan Rasch ModelAkbar Maulana, Resa Respati, Epon Nur'aeni L, Muhammad Rijal Wahid Muharram

DOI: https://doi.org/10.31004/edukatif.v3i5.752

hakikat, manfaat dan pembelajaran dalam pendidikan seni musik. Adapun dari sampel yang di teliti terdapat beberapa guru yang memiliki persepsi negatif terhadap pendidikan seni musik di sekolah dasar, hal tersebut menjadi sebuah keragaman pendangan atau persepsi yang terdapat pada kenyataan di lapangan. Penelitian yang dilakukan memberikan manfaat berupa gambaran deskriptif yang selanjutkan bisa di gunakan dalam pengembangan ilmu pendidikan oleh pemangku kebijakan atau sebagai bahan rujukan bagi penelitian lain terutama dalam proses pendidikan seni musik di Sekolah Dasar.

\section{DAFTAR PUSTAKA}

Afriadi, Putra; Aulia, S. M. (2019). Seni Rupa Yang Meng-Humanis. Seminar Nasional "Guru Pembelajar, Guru Milenial, 220-239.

Fahmi, D. (2020). Persepsi (H. Adamson (Ed.); 1st Ed.). Psikologi Corner.

Faudy, R. (2015). Analisis Persepsi Pelajar Tingkat Menengah Pada Sekolah Tinggi Agama Islam Negeri Kudus. Edukasia: Jurnal Penelitian Pendidikan Islam, 10(1), 189-210. Https://Doi.Org/10.21043/Edukasia.V10i1.791

Julia, J. (2017). Pendidikan Musik: Permasalahan Dan Pembelajarannya Pendidikan Musik: UPI Sumedang Press.

Kukuh Prabawa, A., Susilo Pradoko, ; A M, Cipto, ; \& Handoyo, B. (2021). Perspektif Pendidikan Seni Musik Berorientasi Humanistik. INVENSI (Jurnal Penciptaan Dan Pengkajian Seni), 6(1), 41-52. Http://Journal.Isi.Ac.Id/Index.Php/Invensi/Article/View/4793

Maunah. (2009). Landasan Pendidikan. TERAS.

Morissan. (2018). Metode Penelitian Survei (Riefmanto (Ed.); 1st Ed.). PRENADAMEDIA GROUP.

Muhyidin, A. H. (2012). Meluruskan Arah Pendidikan Indonesia. Alkautsar. Co.

Murtiningsih, H., \& Wiryawan, S. A. (2007). Pembelajaran Seni Musik Di Sekolah Dasar. I, 53-65.

Pane, A. (2017). Belajar Dan Pembelajaran Aprida Pane Muhammad Darwis Dasopang. Fitrah, 03(2), 333352.

Respati, R. (2015). Esensi Pendidikan Seni Musik Untuk Anak. Jurnal Saung Guru, Vol. VII N, 109-115. Http://Jurnal.Upi.Edu/Md/View/3492/Esensi-Pendidikan-Seni-Musik-Untuk-Anak.Html

Rofiah, N. H. (2016). Menerapkan Multiple Intelligences Dalam Pembelajaran Di Sekolah Dasar. Jurnal $\begin{array}{llll}\text { Dinamika Pendidikan } & \text { Dasar, } & \text { 69-79. }\end{array}$ Http://Jurnalnasional.Ump.Ac.Id/Index.Php/Dinamika/Article/View/937/875

Sinaga, B. U. \& S. (2009). Pengembangan Materi Pembelajaran Seni Musik Berbasis Seni Budaya Berkonteks Kreatif, Kecakapan Hidup, Dan Menyenangkan Bagi Siswa Sd/Mi. Harmonia Journal Of Arts Research And Education, 9(2). Https://Doi.Org/10.15294/Harmonia.V9i2.638

Sudaryono. (2018). Metode Penelitian (1st Ed.). Rajawali Pers.

Sugiyono. (2016). Metode Penelitian Pendidikan (Pendekatan Kuantitatif, Kualitatif Dan R\&D) (1st Ed.). Alfabeta CV.

Sumintono, B., \& Widhiarso, W. (2013). Aplikasi Model Rasch Untuk Penelitian Ilmu-Ilmu Sosial (Bambang Trim (Ed.); 1st Ed.). Trim Komunikata Publishing House.

Supardi. (2015). Arah Pendidikan Di Indonesia Dalam Tataran Kebijakan Dan Implentasi. Formatif: Jurnal Ilmiah Pendidikan MIPA, 2(2), 111-121. Https://Journal.Lppmunindra.Ac.Id/Index.Php/Formatif/Article/View/92

Undang-Undang Republik Indnesia Nomor 20 Tahun 2003 Tentang Sistem Pendidikan Nasional. 
2059 Analisis Persepsi Guru Sekolah Dasar Terhadap Pendidikan Seni Musik Melalui Pendekatan Rasch ModelAkbar Maulana, Resa Respati, Epon Nur'aeni L, Muhammad Rijal Wahid Muharram

DOI: https://doi.org/10.31004/edukatif.v3i5.752

Utomo, U. (2013). Analisis Kebutuhan Guru Seni Musik Berbasis Action Learning Di Sekolah Analysis Of Arts Music Teacher Needs In The Context Of Learning Action-Based Implementation In School Arts Music Teacher Needs Analysis In The Context Of Learning Action Based Learning. Harmonia, 13 (2)(1), 110-119.

Yuni, Q. F. (2017). Kreativitas Dalam Pembelajaran Seni Musik Di Sekolah Dasar: Suatu Tinjauan Konseptual. ELEMENTARY: Islamic Teacher Journal, Https://Doi.Org/10.21043/Elementary.V4i1.1980 